\title{
Diagenesis and Genetic Mechanism of Tight Oil Reservoir of the mid-Permian, Jimusar Sag, China
}

\author{
SHAOMIN ZHANG ${ }^{*}$, HAITAO HONG ${ }^{1}$, YINGCHANG \\ $\mathrm{CAO}^{2}$, LONG WEN ${ }^{1}$
}

${ }^{1}$ Exploration and Development Research Institute, PetroChina Southwest Oil \& Gasfifield Company, Chengdu, 610041, China (*correspondence: zhangshaomin0813@126.com) ${ }^{2}$ China University of Petroleum, Qingdao, 266580, China

Diagenesis and formation mechanism of reservoir are the key factors resulting in the strong reservoir heterogeneity and are regarded as the core but difficult subject in tight oil research. The tight oil reservoir of the Permian Lucaogou Formation $\left(\mathrm{P}_{2} \mathrm{l}\right)$ in the Jimusar Sag has complex rock composition. Comparative analysis of porosity, permeability and oil-bearing in different lithofacies shows that the reservoirs are mainly developed in dolomitic siltstone/sandstone, tuffaceous siltstone and tuffaceous dolomite.

The physical property, diagenesis and their mechanism show great differences between different reservoirs with complicated multicomponent. Tuffaceous dolomite reservoir is characterized by strong dissolution and devitrification of medium -basic volcanic material and precipitation of authigenic quartz, accompanied by albite and smectite precipitation and smectite gradually transformation to chlorite. Tuffaceous siltstone is featured by strong dissolution of K-feldspar and pyroclastic, affected by earlier formation water and organic acids and $\mathrm{CO}_{2}$ from organic matter evolution from the adjacent layer. $\mathrm{NaHCO}_{3}$ formation water, smectite illitization and chloritization accelerate K-feldspar dissolution and albite precipitation. So this reservoir is mainly strong dissolved pores of feldspar, medium-basic volcanic debris and pyroclastics. Dolomitic siltstone is characterized by moderate to strong dissolving of feldspar and debris, accompanied with quartz overgrowth and carbonate cement.

There are various carbonate cements, among which $\mathrm{Ca}$ of the early carbonate was from the original sedimentary formation water and $\mathrm{C}$ was derived from microbial fermentation, while the later ferro-carbonate with negative $\delta^{13} \mathrm{C}$ was affected by decarboxylation of organic matter, and abundant $\mathrm{Ca}^{2+} 、 \mathrm{Mg}^{2+} 、$ $\mathrm{Fe}^{2+} 、 \mathrm{Mn}^{2+}$ from volcanic material dissolution.

These three reservoirs can be divided into source-reservoir integrated and source-reservoir interbedded tight oil according to source and reservoir configuration and assemblage. The sourcereservoir integrated tight oil is mainly found in fine-grained ashrich rocks, and the typical lithofacies are muddy tuffite and tuffaceous dolomicrite. While source-reservoir interbedded tight oil is mainly developed in relatively coarse grained ash-poor rocks, reservoirs formed adjacent to the source rocks, represented by dolomitic siltstone/sandstone and tuffaceous siltstone. 